\title{
Hubungan Status Gizi dan Kekerapan Sakit Balita Penghuni Rumah Susun Kemayoran Jakarta-Pusat
}

\author{
Aryono Hendarto, Dahlan Ali Musa
}

\begin{abstract}
Populasi anak merupakan kelompok yang paling mempunyai risiko mengalami kematian di negara berkembang dan kematian tersebut sebagian besar disebabkan oleh penyakit yang dapat dicegah. Angka kematian balita menggambarkan factor-faktor yang lingkungan yang berpengaruh terhadap kesehatan anak. Balita seperti gizi, sanitasi, penyakit menular dan kecelakaan. Rumah merupakan salah satu lingkungan fisik yang mendukung anak dalam melakukan aktifitas fisik untuk mengembangkan kemampuan motorik dengan bermain dan rekreasi untuk mengembangkan kreasi dan menambah pengalaman. Masalah permukiman di perkotaan mempunyai hubungan langsung dan tidak langsung terhadap kesehatan anak. Keterbatasan dana yang dimiliki orang tua, menyebabkan banyak anak di kota besar terpaksa harus tinggal di pemukiman kumuh. Untuk mengatasi hal ini pemerintah memindahkan mereka dari pemukiman yang kumuh ke pemukiman yang layak huni. Karena keterbatasan lahan untuk pembangunan perumahan biasa, maka dibangun rumah susun. Penelitian di beberapa rumah susun melaporkan bahwa ditemukan beberapa factor yang berpengaruh bukan saja terhadap tumbuh kembang, tetapi juga morbiditas dan mortalitas balita. Penelitian cross sectional di rumah susun Kemayoran terhadap 213 balita menunjukkan bahwa prevalensi penyakit selama 1 bulan penelitian sebesar $45.9 \%$. Penyakit-penyakit yang ditemukan pada balita yang tinggal di pemukiman biasa seperti seperti infeksi saluran napas akut, infeksi kulit, panas, batuk kronik berulang, campak, gastroenteritis akut dan kecelakaan juga ditemukan di rumah susun Kemayoran. Ditemukan pula bahwa kekerapan sakit tidak berhubungan dengan status gizi, melainkan dengan kepadatan hunian.
\end{abstract}

Kata kunci: balita, status gizi, kekerapan sakit, prevalensi penyakit, rumah susun.

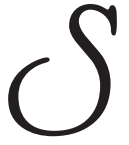

ebagian kematian di negara sedang berkembang terjadi pada anak. Pada tahun 1992 diperkirakan 13 juta anak-anak meninggal di berbagai belahan bumi ini dan sebagian besar akibat penyakit yang sebenamya dapat dicegah. Angka kematian balita menggambarkan faktor-faktor

Dr. Dahlan Ali Musa, Sp.A(K). Subbagian Tumbuh Kembang Pediatri Sosial, Bagian Ilmu Kesehatan Anak FKUI-RSCM.

Alamat Korespondensi:

Dr. Aryono Hendarto, $\mathrm{SpA}(\mathrm{K})$.

Staf Subbagian Gizi \& Penyakit Metabolik. Bagian Ilmu Kesehatan Anak FKUI-RSCM. Jl. Salemba no.6, Jakarta 10430.

Telepon: 021-3915715. Fax.: 021-390 7743. lingkungan yang berpengaruh terhadap kesehatan anak balita seperti gizi, sanitasi, penyakit menular dan kecelakaan. Survei Kesehatan Rumah Tangga di Indonesia tahun 1992 mendapatkan bahwa angka kematian balita adalah $84 \% .^{2}$ Dari data tersebut didapatkan bahwa 5 penyebab terbanyak kematian anak balita adalah diare (23\%), infeksi saluran napas (13\%), difteria, pertusis dan campak $(9,4 \%)$, trauma-keracunan-kecelakaan $(7,3 \%)$, dan malaria $(6,3 \%)$. Beberapa penelitian mengenai penyebab kesakitan anak di daerah perkotaan di negara berkembang telah dilakukan.

Sebagian besar penelitian mendapatkan prevalensi diare dan infeksi parasit tinggi di daerah lingkungan dengan fasilitas, perumahan, air dan sanitasi yang 
buruk.

Masalah pertama pemukiman perkotaan yang mempunyai hubungan langsung dan tidak langsung dengan masalah kesehatan adalah masalah perilaku penduduk yang bermukim di kota besar. Penduduk kota besar di Indonesia umumnya merupakan kelompok pendatang baru dari desa yang sejak kecil telah diresapi oleh nilai-nilai budaya "kampung" yang hidup dalam masyarakat pedesaan. Sehingga konsep-konsep yang dimilikinya, termasuk konsep sehat-sakit, kegiatan rumah tangga serta hubungannya dengan suasana lingkungan "kampung pedesaan" telah berakar dalam jiwa masyarakat kota di Indonesia. Rumah merupakan kebutuhan pokok manusia sebagai tempat tinggal dan tempat berlangsungnya proses kehidupan seseorang sejak ia dilahirkan, masa anak-anak hingga dewasa. Rumah merupakan salah satu lingkungan fisik yang mendukung anak dalam melakukan aktifitas untuk mengembangkan kemampuan motorik dengan bermain, serta melakukan rekreasi untuk mengembangkan kreasi dan menambah pengalaman. $^{3}$

Penduduk kota selalu bertambah; pertambahan ini dapat terjadi akibat proses kelahiran ataupun urbanisasi. Mereka tinggal bersama menempati rumah dengan berbagai kondisi pemukiman. ${ }^{4}$ Karena terbatasnya kemampuan ekonomi disertai terbatasnya pula kernampuan penyediaan perumahan yang layak dan lingkungan yang teratur dan sehat, maka tumbuh kampung-kampung kumuh di perkotaan yang semakin kompleks dan meluas. Pemukiman kumuh pada umumnya diidentikan sebagai daerah hunian dengan tingkat kehidupan dan tingkat sosial penghuni yang sangat rendah di suatu areal perkotaan, sehingga menimbulkan beberapa masalah. ${ }^{5}$ Pada umumnya permukiman kumuh yang terdapat di kota besar, merupakan "pintu masuk" dan "tempat penampungan pertama" pencari kerja yang tidak terampil. Adapun tanda-tanda suatu pemukiman kumuh adalah rumah-rumah yang terdapat di pemukiman tersebut tidak layak huni dan tidak memenuhi kebutuhan tempat tinggal yang wajar karena segalanya seakan-akan serba darurat. Tidak layak huni tersebut dibuktikan dengan keadaan umum rumah-rumah tersebut yang tidak memenuhi syarat teknis, yuridis, dan higienis. ${ }^{6}$ Selain pemukiman kumuh yang juga disebut sebagai slum, di kota-kota besar terdapat pula pemukiman liar yang disebut dengan squatters yang pada umumnya juga merupakan pemukiman kumuh. ${ }^{5}$
Di Jakarta diperkirakan terdapat 4480 ha kampung kumuh dengan 2.337.000 jiwa. ${ }^{5}$ Pemerintah telah berusaha untuk mengurangi pemukiman kumuh dengan melaksanakan berbagai program antara lain Program Perbaikan Karnpung, guna memperbaiki kesehatan lingkungan, memperbaiki kondisi sarana dan prasarana lingkungan yang ada. ${ }^{5}$

Kota Jakarta mempunyai program perbaikan kampung yang disebut Proyek MHT (Mohammad Husni Thamrin) yang mendapat pengakuan nasional dan internasional. Langkah ini kemudian diikuti oleh beberapa kota di Indonesia. Program ini lebih manusiawi karena "tidak mencabut" penduduk dari "akar hidup" atau lingkungannya yang khas. ${ }^{7}$ Sebagian lagi karena terlalu kumuh, tidak dapat diselesaikan dengan Program Perbaikan Karnpung. Karena terbatasnya lahan dan mahalnya harga tanah, maka untuk kampung semacam ini dilakukan Program Peremajaan Lingkungan Kumuh dengan membongkar lingkungan kumuh yang ada dan menggantinya dengan rumah susun yang memenuhi syarat.

Undang-Undang menyebutkan bahwa tujuan dibangun rumah susun antara lain untuk memenuhi kebutuhan perumahan yang layak bagi rakyat, terutama golongan masyarakat berpenghasilan rendah, yang menjamin kepastian hukum dalam pemanfaatannya. Disamping itu juga bertujuan meningkatkan daya guna dan hasil guna tanah di daerah perkotaan dengan memperhatikan kelestarian surnber daya, alam dan menciptakan lingkungan pemukiman yang lengkap, serasi dan seimbang. Pembangunan rumah susun itu harus memenuhi syarat tehnis dan administratif ${ }^{8}$ Salah satu persyaratan tehnis menyebutkan bahwa ruang yang dipergunakan untuk kegiatan sehari-hari harus mempunyai hubungan langsung maupun tidak langsung dengan udara luar dan pencahayaan langsung maupun tidak langsung secara alami dalam jumlah yang cukup, sesuai dengan persyaratan yang berlaku. Dalam rumah susun dan lingkunganya harus disediakan ruangan atau bangunan tempat berkumpul, melakukan kegiatan masyarakat, tempat bermain anak dan kontak sosial lainnya, sesuai dengan standar yang berlaku. ${ }^{9}$ Tetapi membangun rumah susun tersebut bukan pekerjaan yang mudah karena pada saat ini rumah susun masih belum populer dan masih belurn disenangi oleh masyarakat terutama yang berpenghasilan rendah. Terdapat dua masalah pokok yang menyebabkan rumah susun belum disenangi oleh masyarakat. Pertama karena biaya 
pembangunan rumah susun cukup tinggi dan lebih mahal dibandingkan dengan biaya pembangunan tidak susun dan kedua, masyarakat belum menyukai tinggal di rumah susun karena berbagai alasan psikologis dan sosial budaya. ${ }^{5}$

Survei Kesehatan Rumah Tangga 1992 melaporkan bahwa $38,9 \%$ penduduk menempati rumah dengan luas kurang dari $9 \mathrm{~m}^{2}$ per kapita; 36,9\% menempati luas rumah 10-19 $\mathrm{m}^{2}$ per kapita, dan sisanya menempati luas rumah di atas $20 \mathrm{~m}^{2}$ per kapita. ${ }^{1}$ Kebijakan pemerintah membangun rumah susun dengan luas rumah kecil membawa konsekuensi tersendiri yaitu meningkatnya kepadatan hunian. Seperti diketahui bahwa rumah susun yang dibangun pemerintah mempunyai luas, 18,21 , dan $36 \mathrm{~m}^{2}$. Bila tiap rumah mempunyai. anggota keluarga sebanyak 4 orang, ${ }^{10}$ maka dapat diperkirakan bagaimana tingkat kepadatan rumah tersebut. Jika menurut SKRT tahun 1992 jumlah balita hampir 10\% dari jumlah penduduk, ${ }^{2}$ maka berapa balita yang terpaksa harus menempati rumah dengan kepadatan hunian seperti diatas. Padahal telah terbukti rumah yang terIalu padat merupakan media yang baik untuk terjadinya penularan penyakit, selain mengganggu proses tumbuh kembang. Sedangkan proses tumbuh kembang itu sendiri dimulai sejak masa intra uterin, kemudian bayi, balita, remaja, dewasa muda, dewasa, dan seterusnya. ${ }^{11}$ Secara filosofis kesehatan anak merupakan bagian yang tak terpisah dari hak anak, sehingga merupakan tantangan bagi semua orang, institusi dan negara untuk mengupayakan tumbuh kembang anak secara optimal sebagai bagian dari pemenuhan hak anak. ${ }^{12}$ Salah satu dari hak anak tersebut seperti yang tertulis dalarn UU Kesejahteraan Anak adalah hak atas perlindungan terhadap lingkungan hidup yang dapat membahayakan atau menghambat tumbuh kembang secara wajar. ${ }^{13}$ Dari penelitian di beberapa rumah susun di Jakarta terungkap bahwa tidak semua lingkungan pada rumah susun mendukung untuk terciptanya proses kehidupan yang optimal terutama untuk anak- anak. ${ }^{14} \mathrm{Hal}$ ini disebabkan bukan saja karena lingkungan fisik rumah susun belum semuanya memenuhi standar perumahan yang baik, juga beberapa lingkungan lain yang dahulu terdapat di kawasan kumuh tempat mereka berasal kini tidak ada lagi. Seperti misalnya tempat bermain merupakan tempat untuk sosialisasi dan proses tuinbuhnya kreativitas anak-anak. Semua ini dipandang dapat menyebabkan gangguan pada proses tumbuh kembang anak penghuni rumah susun tersebut. Selain gangguan proses tumbuh kembang dikuatirkan pula timbulnya penyakit tertentu pada anak penghuni rumah susun karena struktur dan karakteristik rumah susun tidak sama dengan tempat tinggal mereka yang dahulu. Salah satu faktor yang berperan terhadap kekerapan sakit anak adalah status gizi. Telah banyak yang membuktikan bahwa perjalanan penyakit, respon pengobatan dan prognosis penyakit ikut ditentukan oleh status gizi seorang anak.

Penelitian ini bertujuan untuk mengetahui status nutrisi anak balita penghuni rumah susun, serta apakah ada hubungan status nutrisi lain dengan kekerapan sakit. Faktor lain yang mungkin berhubungan dengan kekerapa sakit juga ikut diteliti. Dengan didapatnya data di atas dapat diketahui apakah status gizi merupakan salah satu masalah kesehatan anak balita di rumah susun, sehingga dapat dibuat prioritas pencegahan, pengobatan dan intervensi kesehatan

\section{Metoda}

Penelitian ini bersifat analitik cross sectional. Data dikumpulkan melalui wawancara, pengamatan lingkungan, pemeriksaan fisik, dan pemeriksaan penunjang. Sasaran wawancara adalah ibu-ibu penghuni rumah susun Kemayoran yang mempunyai anak balita. Sebelum penelitian dilakukan, dimintakan permohonan izin penelitian kepada Direktorat Sosial Politik Permerintah Daerah DKI Jakarta, Direksi Perum Perurnnas Departemen Pekerjaan Umum, Kepala Unit Perumnas Jakarta Kemayoran dan Ketua RW/RT setempat. Penelitian ini dilakukan di rumah susun Kemayoran Jakarta Pusat pada minggu pertama sampai dengan minggu ketiga bulan November 1995. Dipilih lokasi rumah susun Kemayoran, karena rumah susun ini relatif baru dibanding rumah susun lainnya yang ada di Jakarta dengan penghuni berasal dari permukiman kumuh di sekitar Kemayoran yang belum banyak bercampur dengan pendatang luar. Selain itu di rumah susun Kemayoran belum banyak dilakukan penelitian kesehatan, sehingga diharapkan diperoleh kerja sama dan partisipasi yang baik. Subyek penelitian adalah balita yang pada saat penelitian telah tinggal di rumah susun Kemayoran paling sedikit 3 bulan.

Sampel adalah seluruh balita yang orang tuanya merupakan penghuni rumah susun Kemayoran yang memenubi kriteria inklusi. Penelitian ini selain menggunakan analisis bivariat, juga menggunakan 
analisis multivariat dengan metode regresi logistik; karena tidak tersedia rumus besar sampel untuk analisis multivariat maka digunakan rule of thumb. Untuk regresi logistik besar sampel minimal adalah 10 kali jumlah variabel bebas." Kriteria inklusi meliputi balita yang dibuktikan dengan surat keterangan lahir atau surat resmi lainnya seperti kartu menuju sehat, tinggal sebagai penghuni tetap di rumah susun Kemayoran paling sedikit selama 3 bulan yang dibuktikan dengan surat keterangan (kartu keluarga), balita tersebut tidak menderita penyakit sebelum tinggal di rumah susun.

Cara pengambilan data

- Data balita dikonfirmasi dengan mencocokkan pada kartu keluarga yang ada pada RT setempat

- Data mengenai umur, jenis kelamin, urutan kelahiran, pendidikan orang tua, diperoleh dari keluarga dan wawancara

- Data mengenai penyakit balita diperoleh dengan wawancara, pemeriksaan fisis dan bila perlu pemeriksaan penunjang

- Responden adalah ibu-ibu yang mempunyai balita di rumah susun Kemayoran

- Pengumpulan data dilakukan oleh pewawancara dari Badan penelitian dan Pengembangan Kesehatan Depkes dengan latar belakang pendidikan sarjana dan sarjana muda

- Pemeriksaan fisis dilakukan oleh dokter PPDS Ilmu Kesehatan Anak tahap IV (akhir)

- Data lingkungan fisik diperoleh melalui wawancara dan pengamatan

- Sebagai alat pengumpul data digunakan kuesioner.

\section{Definisi Operasional}

Status gizi anak balita (antropometri) yang ditentukan berdasarkan berat badan/tinggi badan yang dibuat oleh Subbagian Gizi Anak FKUI yaitu :

$\mathrm{BB} / \mathrm{TB}>150 \%$ disebut obesitas berat; $>135-150 \%$ : obesitas sedang; > 120-135\%: obesitas ringan; >110$-120 \%$ : gizi lebih; $>90-110 \%$ : gizi baik; >80-90\%: gizi kurang (KKP I); 70-80\%: gizi kurang (KKP II) dan < 70\%: gizi kurang (KKP III). Digunakan indeks tunggal ini agar klasifikasi dapat mencakup seluruh rentang spektrum status gizi mulai dari gizi buruk sampai obesitas. ${ }^{17}$ Berat badan diukur dengan timbangan bayi (Tanita)dan timbangan injak (Detecto) yang telah ditera sebelumnya. Pencatatan dilakukan dalam kg dengan desimal (sensitivitas sampai dengan $0,1 \mathrm{~kg}$ ). Tinggi/ panjang badan diukur dengan kayu yang khusus dirancang untuk mengukur tinggi badan (digunakan pada SKRT 1992) yang mempunyai sensifivitas sampai dengan $0,1 \mathrm{~cm}$. Kepadatan hunian adalah ratio antara jumlah penghuni dengan luas lantai rumah. Suatu rumah dikatakan padat bila setiap $11 \mathrm{~m}^{2}$ dihuni oleh 1 orang atau $14 \mathrm{~m}^{2}$ oleh 2 orang. ${ }^{3}$ Penghasilan keluarga ditentukan berdasarkan jumlah anggota keluarga. Untuk lebih mendapatkan angka yang sebenarnya dilakukan perincian mengenai pengeluaran sehari-hari biaya transportasi keluarga, biaya sekolah, listrik gas, air, majalah/koran dan lain-lain. Penghasilan keluarga diklasifikasikan berdasarkan laporan Bank Dunia 1987, tentang pendapatan perkapita perbulan, negara sedang berkembang dengan kategori sebagai berikut: penghasilan rendah bila kurang dari Rp.59.000,- perkapita/bulan; penghasilan sedang antara Rp.59.000-Rp.237.000,- perkapita/bulan, sedangkan penghasilan tinggi bila lebih dari Rp.237.000 perkapita/bulan ( kurs pada tahun tersebut 1 dolar Amerika = Rp. 1625,-). Kekerapan sakit didefinisikan sebagai kejadian sakit yang dialami oleh balita 1 kali atau lebih dalam sebulan atau minimal 4 kali dalam 1 tahun. ${ }^{19}$

\section{Pengolahan dan analisis data}

Pemasukan data dilakukan dengan program yang dipakai dalam analisis data, yaitu Epi Info, kemudian dilanjutkan dengan program SPSS/PC+. Sedangkan analisis data dilakukan dengan 2 tahap. Analisis akhir yang digunakan adalah regresi logistik dengan alasan variabel tergantung pada penelitian ini bersifat nominal dikotom sedangkan variabel bebasnya berskala katagorial (nominal) dan numerik. ${ }^{51}$ Penentuan variabel bebas mana yang diikutsertakan dalam analisis tidak hanya tergantung dari bermakna atau tidaknya koefisien regresi semata; walaupun koefisien regresi tidak menunjukkan bermakna tetapi bila secara substansi teori dan menurut logika (make sense) dapat dipertanggungjawabkan maka variabel tersebut dapat diikutsertakan.

\section{Hasil}

\section{Karakteristik Sampel Responden}

Berdasarkan pendataan di lokasi rumah susun, didapatkan kurang lebih 1278 keluarga sebagai penghuni rumah susun Kemayoran. Dari data yang diperoleh ditentukan kurang lebih 283 anak berusia 
di bawah lima tahun yang terdiri dari 79 balita tinggal di Blok Apron dan 204 balita tinggal di Blok Dakota. Dari jumlah tersebut 225 balita memenuhi kriteria inklusi, tetapi yang diikutsertakan dalam penelitian hanya 213 balita karena 12 kuesioner tidak lengkap. Jumlah 213 balita tersebut berasal dari 180 responden/keluarga yaitu 152 responden mempunyai 1 orang balita, 29 responden mempunyai 2 orang balita, dan 1 responden mempunyai 3 orang balita. Jumlah anggota keluarga terkecil adalah 3 orang dan jumlah anggota keluarga terbesar adalah 8 orang. Secara rerata maka tiap keluarga mempunyai 4 anggota keluarga.

Dari 213 balita yang diteliti $40(18,8 \%)$ balita berumur kurang dari 12 bulan, $60(28,2 \%)$ balita berumur antara $12-<24$ bulan; $43(21,2 \%)$ balita berumur antara $24-<36$ bulan, $28(13,1 \%)$ balita berumur antara $36-<48$ bulan dan $42(19,7 \%)$ balita berumur $48-<60$ bulan. Nilai rerata umur ini adalah 27,9 bulan (SD 16,7); 44,6\% lelaki dan sisanya perempuan. Seluruh balita tersebut tinggal tersebar

Tabel 1. Sebaran responden menurut umur, pendidikan, pekerjaan KK dan status rumah

\begin{tabular}{lcc}
\hline Kriteria Parameter & $\mathrm{N}$ & $\%$ \\
\hline Umur (tahun) & 3 & \\
$\quad<20$ & 123 & 1,7 \\
$20-30$ & 49 & 68,3 \\
$31-40$ & 5 & 27,2 \\
$>40$ & & \\
Pendidikan & 0 & 0 \\
Tidak sekolah & 36 & 20,0 \\
SD & 40 & 22,2 \\
SLTP & 85 & 47,2 \\
SLTA & 19 & 10,6 \\
PT & & \\
Pekerjaan KK* & 4 & 2,2 \\
Tidak bekerja & 9 & 5,0 \\
Buruh & 16 & 8,9 \\
PNS/ABRI/Pensiunan & 151 & 83,9 \\
Swasta & & \\
Status rumah & 47 & 26,1 \\
Milik sendiri & 129 & 71,7 \\
Sewa kontrak & 4 & 2,2 \\
Menumpang & 180 & 100 \\
Jumlah & & \\
\hline
\end{tabular}

${ }^{*} \mathrm{KK}=$ Kepala keluarga hampir merata dari lantai II sampai dengan V. Tabel 1 memperlihatkan sebagian besar responden (ibu) berumur di bawah 30 tahun, usia termuda adalah 19 tahun dan tertua 44 tahun dengan rerata umur responden 27,9 tahun (SD 5,0). Sedangkan umur kepala keluarga termuda adalah 20 tahun dan tertua 60 tahun dengan rerata 34,0 tahun (SD 6,8).

Sebanyak 29 kepala keluarga $(16,1 \%)$ berpendidikan Perguruan Tinggi, 109 (60,5\%) berpendidikan SLTA, 21 kepala keluarga $(11,7 \%)$ berpendidikan SLTP, 19 kepala keluarga (10,6\%) berpendidikan SD dan hanya 2 kepala keluarga $(1,1 \%)$ yang tidak sekolah. Lebih dari $70 \%$ responden mendiami rumah mereka secara sewa kontrak, baik dari pemilik maupun dari Perum Perumnas sebagai pengelola rumah susun tersebut. Sebanyak 60 keluarga $(28.2 \%)$ berpenghasilan rendah, 129 keluarga $(60,6 \%)$ berpenghasilan keluarga sedang, sisanya yaitu 24 keluarga $(11,2 \%)$ berpenghasilan tinggi. Sebanyak 155 balita $(73,7 \%)$ mempunyai ibu yang bekerja sedangkan sisanya sebanyak 58 balita $(26,3 \%)$ mempunyai ibu yang tidak bekerja. Hanya 36 balita. $(16,9 \%)$ tinggal di rumah yang padat, sedangkan sebagian besar yaitu 177 balita $(83,1 \%)$ tinggal di rumah yang tidak padat. Sebagian besar yaitu 179 balita $(84,0 \%)$ mempunyai sanitasi lingkungan yang baik, sedangkan yang mempunyai sanitasi lingkungan cukup dan kurang baik masing-masing 24 balita $(11,3 \%)$ dan 10 balita (4,7\%). Sebanyak 41 (19,3\%) balita mempunyai ibu dengan corak reproduksi kurang sedangkan balita yang mempunyai ibu dengan corak reproduksi, cukup dan baik masing-masing 61 (28.6\%) balita dan 111 (52.10\%) balita. Sejumlah 41 (19.3\%) balita mempunyai pola pengasuhan anak yang kurang, $83(38.0 \%)$ cukup, sedangkan sisanya. yaitu 89 (41.7\%) balita mempunyai pola pengasuhan anak yang baik.

Hampir semua suku bangsa. yang ada di Indonesia terwakili di rumah susun ini, dan sebagian besar didominasi oleh suku Jawa.

\section{Pola penyakit}

Pada saat penelitian berdasarkan anammesis, pemeriksaan fisis dan pemeriksaan penunjang ditemukan sebanyak 65 kasus penyakit dan selama 1 bulan terakhir ditemukan 130 kasus (Tabel 2). Sedangkan dalain kurun waktu 3 bulan terakhir ditemukan sebanyak 176 kasus penyakit yang diderita oleh balita di rumah susun Kemayoran. Lebih dari 50\% penyakit yang ditemukan adalah infeksi saluran napas akut, kemudian ber- 
Sari Pediatri, Vol. 4, No. 2, September 2002

Tabel 2. Pola penyakit balita pada saat penelitian, 1 bulan dan 3 bulan terakhir

\begin{tabular}{|c|c|c|c|c|c|c|}
\hline \multirow[b]{2}{*}{ Pola penyakit } & \multicolumn{2}{|c|}{ Saat penelitian } & \multicolumn{2}{|c|}{1 bulan terakhir } & \multicolumn{2}{|c|}{3 bulan terakhir } \\
\hline & $\mathrm{n}$ & $\%$ & $\mathrm{n}$ & $\%$ & $\mathrm{n}$ & $\%$ \\
\hline ISPA & 44 & 67,7 & 69 & 53,1 & 94 & 53,4 \\
\hline Observasi demam & 2 & 3,1 & 18 & $1.3,8$ & 35 & 19,8 \\
\hline $\mathrm{BKB}$ & 5 & 7,7 & 12 & 9,2 & 16 & 9,1 \\
\hline Kecelakaan & 0 & 0 & 10 & 7,7 & 10 & 5,7 \\
\hline Gastroenteritis & 8 & 12,31 & 10 & 7,7 & 10 & 5,7 \\
\hline Campak & 3 & 4,7 & 8 & 6,1 & 8 & 4,5 \\
\hline Anemia & 1 & 1,5 & 1 & 0,8 & 1 & 0,6 \\
\hline Infeksi kulit & 1 & 1,5 & 1 & 0,8 & 1 & 0,6 \\
\hline Stomatitis & 1 & 1,5 & 1 & 0,8 & 1 & 0,6 \\
\hline Jumlah & 65 & 100 & 130 & 100 & 176 & 100 \\
\hline
\end{tabular}

Keterangan : ISPA : infeksi saluran pernafasan akut BKB : batuk kronik berulang, 1 orang balita dapat menderita sakit lebih dari 1 kali.

turut-turut kasus yang ditemukan adalah observasi demam, batuk kronik berulang, kecelakaan, gastroenteritis, anemia dan infeksi kulit. Kejadian penyakit selama 1 bulan terakhir adalah 45,9\%. Baik dari data primer maupun sekunder selarna 1 tahun terakhir tidak dijumpai balita yang meninggal dunia di rumah susun Kemayoran.

Proporsi pasien terbanyak adalah kelompok umur $12-<24$ bulan $(28,5 \%)$ dan yang terkecil adalah kelompok umur $36-<48$ bulan (11,6\%). Diantara 90 jenis penyakit balita $(69,2 \%)$ diderita oleh balita kelompok 3 tahun ke bawah dan 56,7\% diantaranya adalah ISPA (Tabel 3).

Jumlah balita perempuan (56,9\%)yang menderita sakit pada penelitian ini lebih banyak dibandingkan dengan balita lelaki $(43,1 \%)$.

\section{Status gizi}

Hampir semua status gizi ditemukan pada penelitian ini, kecuali status gizi buruk (Tabel 4). Sebanyak 29 $(13,6 \%)$ balita mempunyai status gizi kurang (KKP 11), 66 (3 1,0\%) balita mempunyai status gizi kurang (KKP 11), 103 (48,4\%) balita gizi baik, $9(4,2 \%)$ balita status gizi lebih dan sisanya $6(2,8 \%)$ balita obesitas. Dari 6 balita yang mempunyai status gizi obesitas, 2 diantaranya mengalami obesitas sedang. Kekerapan sakit ditemukan hampir sama banyak antara kelompok balita dengan status gizi baik dan gizi lebih. Tampak kekerapan terkecil ditemukan pada balita dengan status gizi kurang, namun secara statistik tidak terdapat hubungan antara status gizi dengan kekerapan sakit.

Tabel 3. Pola penyakit menurut kelompok umur balita

\begin{tabular}{lcccccc}
\hline & \multicolumn{5}{c}{ U m u r (bulan) } \\
Pola penyakit & $<12$ & $12-<24$ & $24-<36$ & $36-<48$ & $48-<60$ & Jumlah (\%) \\
\hline ISPA & 11 & 23 & 17 & 7 & 1 & $69(53,1)$ \\
Observasi demam & 9 & 3 & 1 & 3 & 2 & $18(13,8)$ \\
BKB & 1 & 4 & 1 & 3 & 3 & $12(9,2)$ \\
Kecelakaan & 3 & 2 & 1 & 0 & 4 & $10(7,7)$ \\
Gastroenteritis & 2 & 4 & 2 & 1 & 1 & $10(7,7)$ \\
Campak & 2 & 0 & 2 & 1 & 3 & $8(6,1)$ \\
Lain-lain & 0 & 1 & 1 & 0 & 1 & $3(2,4)$ \\
\hline Jumlah (\%) & $28(21,5)$ & $37(28,5)$ & $25(19,2)$ & $15(11,6)$ & $25(19,2)$ & $130(100)$ \\
\hline
\end{tabular}


Tabel 4.Sebaran Balita Menurut Status Gizi dan Kekerapan Sakit

\begin{tabular}{lccccc}
\hline Status Gizi & \multicolumn{3}{c}{ Kekerapan sakit } & Jumlah \\
\cline { 2 - 5 } & Ya & $\%$ & Tidak & $\%$ & \\
\hline kurang (KKP I/II/III) & 30 & 31,9 & 65 & 68,1 & 95 \\
baik & 46 & 44,7 & 57 & 55,3 & 103 \\
lebih & 4 & 44,4 & 5 & 55,6 & 9 \\
Obesitas & 2 & 33,3 & 4 & 66,7 & 6 \\
\hline Jumlah & 82 & 38,5 & 131 & 61,5 & 213 \\
\hline
\end{tabular}

Koreksi Yate's $\mathrm{X}^{2}=3,40, \mathrm{df}=33, \mathrm{p}=0,33$

\section{Status imunisasi}

Hanya $3(1,4 \%)$ balita yang mempunyai status imunisasi buruk, selebihnya yaitu 49 balita $(23,0 \%)$ dan 161 balita $(75,6 \%)$ masing-masing mempunyai status imunisasi cukup dan baik. Dari 3 balita dengan status imunisasi buruk seluruhnya menunjukkan tidak kerap sakit. Balita dengan status imunisasi cukup $(42,8 \%)$ ternyata lebih kerap sakit dibandingkan balita dengan status imunisasi baik (37,9\%). Tetapi secara statistik tidak ada hubungan antara status imunisasi dengan kekerapan sakit.

\section{Faktor yang Berhubungan dengan Kekerapan Sakit Balita}

Untuk mengetahui hubungan antara kelompok variabel penelitian secara keseluruhan, maka dilakukan analisis regresi logistik dengan sistim forward stepwise menggunakan metode statistik Wald. Aplikasi statistik yang digunakan adalah SPSS/PC+. Hal ini dilakukan dengan memperhatikan kelompok variabel bebas seperti yang terdapat dalam batasan operasional.

Dari hasil analisis regresi logistik terlihat bahwa tidak semua variabel yang dimasukkan dalam analisis tersebut menunjukkan adanya hubungan atau pengaruh (Tabel 5). Variabel yang menunjukkan adanya hubungan dengan kekerapan sakit di rumah susun tersebut hanya. kepadatan hunian $(\mathrm{p}=0,03)$.

\section{Diskusi}

Sebagian besar responden pada penelitian ini $(68,3 \%)$ berumur 20-30 tahun, Hal ini berarti sebagian besar responden berada dalam usia produktif. Demikian pula hampir separuh responden berpendidikan SLTA dan
Tabel 5. Hasil analisis regresi logistik antara beberapa variabel bebas dengan variabel kekerapan sakit

\begin{tabular}{lccc}
\hline Variabel & $\mathrm{B}$ & $\mathrm{p}$ & Ratio Odds \\
\hline Status gizi & 0,6355 & 0,07 & 1,0215 \\
Status imunisasi & 0,6355 & 0,06 & 1,0215 \\
Kepadatan hunian & 0,9132 & 0,03 & 2,4923 \\
Corak reproduksi ibu & $-0,2468$ & 0,24 & 0,7813 \\
Pola asuh & $-0,2554$ & 0,23 & 0,7747 \\
Penghasilan keluarga &,- 0798 & 0,76 & 1,0505 \\
\hline
\end{tabular}

sebagian besar kepala keluarga bekerja di sektor swasta. Penemuan ini hampir sama dengan penelitian yang dilakukan oleh Fakultas Kesehatan Masyarakat UI, ${ }^{14}$ hanya saja jumlah kepala keluarga yang bekerja di sektor swasta lebih sedikit. Selama penelitian dilakukan penentuan pola penyakit dalam 1 bulan terakhir, dana pada responden ditanyakan penyakit yang diderita balitanya pada kurun waktu 3 bulan sebelumnya. $\mathrm{Hal}$ ini bertujuan untuk membandingkan apakah ada perbedaan pola penyakit balita di rumah susun Kemayoran dalam kaitan dengan musim. Disebutkan dalam kepustakaan bahwa jenis penyakit dipengaruhi oleh perbedaan musim, yaitu pada musim tertentu dijumpai jenis penyakit tertentu pula. ${ }^{20,21} \mathrm{Di}$ Indonesia penyakit ISPA lebih banyak ditemukan pada musim hujan (bulan Oktober-Maret). ${ }^{22}$ Penelitian ini dilakukan pada bulan November (musim hujan) dan kurun waktu 3 bulan sebelum penelitian adalah musim panas.

Disamping itu ditentukan pula jenis penyakit yang diderita balita pada saat penelitian berlangsung dengan melakukan anamnesis, pemeriksaan fisis, dan pemeriksaan penunjang bila diperlukan; hal ini diperlukan untuk melihat perbedaan pola penyakit diatas. Walaupun demikian disadari adanya kelemahan dalam metode ini yaitu kemungkinan timbulnya bias 
karena responden tidak dapat dengan tepat mengingat penyakit anaknya dalam waktu 3 bulan terakhir. Dari data yang ada ternyata jenis penyakit pada kurun waktu 3, 1 bulan terakhir, dan saat penelitian dilakukan tidak jauh berbeda; perbedaan pada jumlah penyakit yang ditemukan.

Data pola penyakit dalam kurun waktu 3 bulan terakhir tidak dilakukan pengolahan/analisis, untuk menghindari bias pada saat pengambilan data penyakit (recall bias). Pola penyakit yang ditemukan pada penelitian ini adalah infeksi saluran napas akut (ISPA), observasi demam, kecelakaan, batuk kronik berulang, campak, gastroenteritis dan 3 penyakit yang dikelompokkan dalam lain-lain yaitu anemia, infeksi kulit, dan stomatitis. Bila dibandingkan dengan pola penyakit yang terdapat pada Survei Kesehatan Rumah Tangga, Depkes 1986 ( SKRT) temuan ini tidak jauh berbeda. Urutan pola penyakit terbanyak menurut SKRT 1986 berturut-turut adalah infeksi saluran napas akut, diare, infeksi kulit, bronkitis/asma, penyakit susunan syaraf, difteri/pertusis/campak, malaria, dan penyakit gigi, mulut dan saluran cerna. Disamping itu masih terdapat beberapa penyakit lain diantaranya kecelakaan/cidera tetapi dalam frekuensi yang sangat kecil..$^{23}$ Sedangkan pada SKRT 1992 penyebab terbanyak kesakitan balita berturut-turut infeksi saluran napas atas, diare, infeksi/ parasit lain, campak/difteri/pertusis, penyakit susunan syaraf, kecelakaan, gangguan gizi dan bronkitis/ emfisema/asma. ${ }^{2}$ Maka, selain infeksi saluran napas atas yang sama-sama menjadi penyebab utama kesakitan balita, penyebab penyakit lainnya hanya berbeda pada proporsi. Penelitian yang dilakukan oleh Fakultas Kesehatan Masyarakat Universitas Indonesia pada tahun 1987 di rumah susun Kebon Kacang Jakarta Pusat yang juga dikelola oleh Perum. Perumnas menunjukkan bahwa lima penyakit terbanyak berturut-turut adalah batuk-pilek-panas, paru, THT, sakit mata, serta kulit dan kelamin. ${ }^{14}$ Walaupun hasil ini tidak begitu saja dapat dibandingkan karena sampel pada penelitian tersebut bukan hanya balita (semua golongan umur) dan diagnosis ditegakkan berdasarkan kelainan sistim organ, tetapi terlihat bahwa pola penyakit tidak jauh berbeda dengan yang ditemukan di rumah susun Kemayoran. Penelitian lain oleh Nainggolan dkk pada tahun 1989 di beberapa rumah susun di Jakarta memberikan hasil yang serupa. ${ }^{24}$ Meskipun berasal dari data sekunder dan bukan hanya pada populasi balita, tetapi infeksi saluran napas akut juga merupakan penyakit terbanyak. Pada penelitian ini frekuensi penyakit yang dapat dicegah dengan imunisasi hanya sedikit, seluruhnya penyakit campak. Disamping itu dari 130 penyakit balita yang terdeteksi selama 1 bulan terakhir sebelum penelitian 90 penyakit diantaranya $(69,2 \%)$ dialami oleh balita yang berumur 3 tahun atau kurang dengan frekuensi terbanyak $(56,7 \%)$ penyakit ISPA. Hal ini patut mendapat perhatian dari aparat kesehatan yang berwenang, karena dengan kepadatan hunian yang cukup tinggi penularan penyakit ini akan lebih mudah. Disamping itu bila sejak bayi sering menderita penyakit ISPA, dikuatirkan akan menimbulkan hiperreaktivitas bronkus yang merupakan dasar terjadinya penyakit asma. ${ }^{25}$

Bila pada SKRT tahun 1986 dan 1992 frekuensi penyakit campak sebesar $11,1 \%$ dan $9.8 \%$, maka pada penelitian ini hanya ditemukan $6,1 \%$. Secara epidemiologi seharusnya jumlah balita di rumah susun yang menderita campak akan lebih besar mengingat tingkat kepadatan hunian yang lebih tinggi.

Penggolongan status gizi pada penelitian ini berbeda dengan SKRT tahun 1992. Apabila SKRT tahun 1992 menggunakan klasifikasi status gizi berdasarkan WHO-NCHS, penelitian ini menggunakan klasifikasi berdasarkan indeks tunggal berat badan/tinggi badan yang disusun oleh Subbagian Gizi Anak Bagian Ilmu Kesehatan Anak FKUl RSCM. ${ }^{17}$ Maksud penggunaan klasifikasi ini agar seluruh spektrum status gizi mulai dari gizi buruk sampai gizi lebih dapat dideteksi. Hal ini berdasarkan asumsi bahwa tingkat penghasilan keluarga yang tinggal di rumah susun lebih baik dari tingkat pendapatan masyarakat desa yang merupakan sebagian besar sampel SKRT tahun 1992. Namun, untuk keperluan analisis dan agar hasil dapat dibandingkan dengan kepustakaan lain maka status gizi diklasifikasikan menurut gizi kurang (KKPI/II/III), gizi baik, gizi lebih dan obesitas. Pada penelitian ini hampir semua spektrum gizi ditemukan kecuali gizi buruk. Status gizi yang paling banyak ditemukan adalah gizi baik $(48,8 \%)$; hasil yang sama ditemukan pada SKRT tahun 1992 tetapi dengan jumlah yang lebih besar $(58,9 \%)$. Banyaknya jumlah status gizi baik pada penelitian ini diduga disebabkan karena lebih $70 \%$ responden mempunyai tingkat penghasilan menengah dan tinggi, hal ini akan menyebabkan pengadaan makanan pokok untuk menjamin tersedianya zat gizi yang memadai dan adekuat dapat terpenuhi. ${ }^{26}$ Kekerapan sakit cenderung ditemukan pada balita yang mempunyai gizi baik, namun terbukti status gizi ini tidak barhubungan 
dengan kekerapan sakit. Hal ini tentunya berlawanan dengan kepustakaan yang pernah dilaporkan. Telah diketahui bahwa terdapat interaksi antara keadaan gizi, status imun dan kejadian infeksi. Gizi kurang menghambat reaksi imunologis, berhubungan dengan tingginya prevalensi dan beratnya penyakit infeksi. ${ }^{27}$ Bahkan status gizi ini bukan saja mempengaruhi kekerapan sakit balita, tetapi menunjukkan bahwa anak-anak dengan gizi buruk mempunyai angka kematian hampir 4 kali dibandingkan anak dengan gizi baik. Anak dengan gizi kurang yang mengalami penyakit infeksi saluran napas bawah akut cenderung menunjukkan angka kematian yang lebih tinggi. ${ }^{27} \mathrm{Hal}$ lain yang juga mempengaruhi status gizi adalah faktor budaya, dalam hal ini persepsi dan kepercayaan terhadap, makna makan dan makanan. Nafsu makan dan apa yang diperlukan untuk memuaskannya adalah suatu konsep budaya yang dapat sangat berbeda antara satu kebudayaan dengan kebudayaan lainnya.

Sebaliknya lapar menggambarkan suatu kekurangan gizi yang mendasar dan merupakan suatu konsep fisiologis. Dalam beberapa masyarakat definisi lengkap dari makanan tidak dapat merujuk kepada konsep makanan dan waktu makan. Di Meksiko, misalnya makanan adalah yang disantap pada jam-jam makan. Makanan lain seperti makanan ringan, buah-buahan atau makanan lain untuk sajian tamu bukan dianggap sebagai makanan. ${ }^{28}$ Kepercayaan juga memegang peranan penting dalam mempengaruhi status gizi. Pada sebagian masyarakat tertentu di Indonesia misalnya, daging dianggap menimbulkan cacingan pada anak sehingga dianggap lebih baik tidak memberikan daging kepada anak. ${ }^{29}$

Berbeda dengan hasil yang terdapat pada SKRT tahun 1992 yang melaporkan 26,1\% balita belum pernah mendapat imunisasi, pada penelitian ini hanya 3 balita $(1,4 \%)$ yang belurn pernah mendapat imunisasi sama sekali. Sedangkan untuk status imunisasi baik, hasil yang didapat pada penelitian ini (62,29\%) lebih tinggi dari SKRT 1992 (43,7\%). Hasil status imunisasi yang lebih baik ini mungkin disebabkan karena sebagian besar responden berpendidikan menengah yaitu tamat sekolah lanjutan atas atau lebih tinggi. Dengan pendidikan yang lebih tinggi tersebut akan mempengaruhi pola asuh anak, pengetahuan kesehatan ibu dan pemilihan upaya pengobatan/kesehatan. Disamping itu tingkat penghasilan keluarga yang tinggi ikut mempengaruhi status imunisasi, karena untuk imunisasi memerlukan dana bukan saja untuk pelayanan kesehatan tetapi juga untuk transportasi. ${ }^{30}$

\section{Faktor yang Berhubungan dengan Kekerapan Sakit Balita}

Dari beberapa variabel yang dilakukan analisis regresi logistik, ternyata variabel status gizi tidak berhubungan dengan kekerapan sakit dan hanya variabel kepadatan hunian yang berhubungan dengan kekerapan sakit. $\mathrm{Hal}$ ini dapat dimengerti karena 118 (55.3\%) balita mempunyai status gizi baik atau gizi lebih, sisanya mempunyai status gizi kurang dan tidak ditemukan balita yang mempunyai status gizi buruk. Untuk variabel kepadatan hunian, menunjukkan kontribusi yang lebih besar yaitu $0,9 \%\left(r^{2}=0.009\right)$. Penelitian membuktikan bahwa kepadatan hunian mempermudah penularan penyakit khususnya penyakit saluran napas, karena jumlah penghuni sangat berpengaruh terhadap jumlah koloni kuman. ${ }^{31} \mathrm{Di}$ samping itu rurnah yang terlalu padat dapat mempengaruhi tumbuh kembang anak. ${ }^{4,32}$

\section{Kesimpulan}

Prevalensi penyakit selama kurun waktu 1 bulan pada balita di rumah susun Kemayoran adalah 45,9\% dengan penyakit terbanyak adalah infeksi saluran napas atas diikuti berturut-turut, observasi panas, kecelakaan, batuk kronik berulang, campak dan gastroenteritis. Kepadatan hunian di rumah susun Kemayoran 4,5 m2/ kapita dan berhubungan dengan terjadinya kekerapan sakit. Pada penelitian ini status gizi tidak berhubungan dengan kekerapan sakit.

\section{Daftar Pustaka}

1. United Nations Children's Fund. Annual report 1993. h. 7-18.

2. Bakri Z, Supriyanto E, Naseh S, Hastoety PD, Sudiarso. Survei kesehatan rumah tangga 1992. Jakarta: Badan Litbangkes Depkes-BPS, 1994.

3. Nugroho S. Rumah sehat. Direktorat Higeine dan Sanitasi Departemen Kesehatan, 1990.

4. Achmadi UF. Indikator pemukiman sehat di perkotaan. Maj Kes Mas Indones 1991; 19:636-40.

5. Yudohusodo S, Salam S. Rumah untuk seluruh rakyat. Jakarta: Yayasan Padamu Negeri, 1991. h. 341-64.

6. Halim AR. Hak milik kondominium dan rumah susun. 
Jakarta: Puncak Karma; 1990. h. 293-320.

7. Marbun BN. Kota Indonesia masa depan masalah dan prospek. Jakarta: Erlangga, 1990;75-84.

8. Undang-Undang Republik Indonesia No. 16 Tentang Rumah Susun, 1985.

9. Peraturan Pemerintah Republik Indonesia No. 41988 tentang Rumah susun.

10. Budiarso R, Susanto SS, Bakri Z, Santoso SS, Kristanti CM, Santoso SS dkk. Prosiding seminar survai kesehatan rumah tangga 1986. Jakarta: Badan Penelitian dan Pengembangan Depkes, 1987.

11. Trastotenojo MS. Pembangunan dan tumbuh kembang anak. Disampaikan pada Kongres Nasional Ilmu Kesehatan Anak IX, Semarang, 16-19 Juni, 1993.

12. Rahardjo S. Hak dan perlindungan anak di Indonesia. Disampaikan pada Konggres Nasional Ilmu Kesehatan Anak ke-X, Semarang, 16-19 Juni, 1993.

13. Ranuh IGN The right of children, present and immediate future: country report. Disampaikan pada the 6th Asean Pediatrics Federation Conference, Bali, 1992.

14. Fakultas Kesehatan Masyarakat UI. Penelitian aspek sosial ekonomi dan kesehatan masyarakat penghuni rumah susun Kebon Kacang DKI Jakarta. Jakarta, 1987.

15. Anorital, Yuningprapti I Review hasil penelitian ekologi kesehatan yang dilaksanakan oleh Badan Litbangkes selama Pelita V. Media Litbangkes 1994; 4:24-32.

16. Budiarso LR, Setiady IF, Soesanto SS, Siagian BTP, Bakri Z, Simanjuntak C. Pedoman pewawancara survei kesehatan rumah tangga, Jakarta 1985-1986.

17. Samsudin. Penilaian keadaan gizi dan pertumbuhan: Tata cara, kegunaan dan keterbatasan. Dalam: Samsudin, Nasar SS, Sjanf DR, penyunting. Masalah gizi ganda dan tumbuh kembang anak. Naskah lengkap Pendidikan Kedokteran Berkelanjutan Ilmu Kesehatan Anak FKUI XXXV. Jakarta: Bina Rupa Aksara, 1995. h. 149-58.

18. Gibson RS. Nutritional assessment. A laboratory manual. NewYork: Oxford University Press, 1993. h. 41-101.

19. Boat TF. Doershuk Cf, Stern RC, Higgie AD. Infection of the upper respiratory tract. Dalam: Behrman RE, Vaughn VC, penyunting. Nelson's text book of pediatric, edisi ke- 13. Philadelphia Saunders; 1987. h. 869-87.
20. Azwar A. Pengantar epidemiologi. Edisi-1. Jakarta: Binarupa Aksara, 1988. h. 17-38.

21. Hanlon P. Factors influencing vaccination compliance in peri-urban Gambian children. J Trop Med Hyg 1988; 99:29-33.

22. Krzysko R.WHO programme on ARI in regional perpective - SEAR. Dibacakan pada Lokakarya Nasional Ke-1 Penanggulangan infeksi pernapasan akut, Cipanas, 9-12 April 1984.

23. Budiarso R, Bakri Z, Santoso SS. Data statistik survai kesehatan rumah tangga. 1980. Jakarta: Badan Penelitian dan Pengembangan Depkes, 1987.

24. Barros FC, Victoria CG, Vaughn P, Capellari MM. Perinatal risk in third World Cities. Bull WHO 1987; 6:322-4.

25. Fox JP, Hall CE, Elveback LR. Epidemiology man and disease. London: Mac Millan, 1970. h. 31-46.

26. Mosley VH, Chen LC. Suatu kerangka analisis untuk studi kelangsungan hidup anak di negara berkembang. Dalam: Singarimbun M, penyunting. Kelangsungan hidup, anak. Yogyakarta: Gadjah Mada University Press, 1988. h. 205-42

27. Alisyahbana A. Aspek kesehatan gizi dan balita. Dalam: Kardjati S, Alisyahbana A, Kusin JA, penyunting. Bandung: Yayasan Obor Indonesia, 1985. h. 53-69.

28. Media Y. Makanan dan gizi dalam konteks budaya. Maj Kes Mas Indones 1995; 9:26-30,

29. Edith W. Gangguan makanan dan gizi pada anak.Tinjauan dari sudut kesehatan Jiwa. Disampaikan pada Simposium sehari pengaruh zat makanan tambahan terhadap anak, Jakarta 18 September 1994.

30. Sularyo TS, Sudjarwo SR. Coverage of immunization of underfives in Marunda, North Jakarta. Disampaikan pada Konggres Nasional Ilmu Kesehatan Anak VIII, Ujung Pandang 1990.

31. Poerno K. Pengaruh cuaca serta lingkungan rumah terhadap jumlah koloni kuman di kompleks perumahan TNI-AL Surabaya. Tesis. Jakarta: Fakultas Kesehatan Masyarakat Universitas Indonesia, 1983.

32. Ancok D. Pengaruh rumah kecil terhadap perkembangan anak. Maj Kes Masyarakat Indones I988; 11:618-20. 